\title{
Evolution and Thinking of the Functions of Western Government's Public Service Provision
}

\author{
Deng Keyu ${ }^{1}$ \\ ${ }^{1}$ School of Government Management, Beijing Normal University, Beijing, China \\ bnudengky@163.com
}

\begin{abstract}
The history of public service supply reflects the evolution of government functions. This article sorts out the development process of the public service provision function of the Western government from the perspective of the change of the main body of public service provision. The first stage was before the 20th century, when the government played a limited role in the provision of public services, with households, private organizations, and social organizations performing public service provision functions. The second phase was from the early 20th century to the 1970s, when the government gradually monopolized public service provision. The third stage is from the 1980s to the present. The wave of marketization of public services has swept the world. The government gradually withdrew from some public service supply areas and cooperated with social organizations to provide public services. We can get some inspiration from the history combing of how the Chinese government should effectively provide public services.
\end{abstract}

Keywords: public services, government functions

\section{INTRODUCTION}

On October 18, 2017, the report of the Nineteenth National Congress emphasized that socialism with Chinese characteristics has entered a new era, and the main contradictions in our society have been transformed into the contradictions between the people's increasing needs for a better life and unbalanced and inadequate development. The ever-increasingly beautiful life of the people calls for more comprehensive and high-quality public services. On the other hand, China's public service level is low, its coverage is narrow, and its security is poor. There are many problems with fertility, pensions, medical care, and housing security. Therefore, by reviewing the evolution of the public service provision function of western governments, it provides some references for how to improve the quality of public services and realize the effective supply of public services in China.

\section{BACKGROUND}

\subsection{Definition of public services}

At present, scholars have many definitions of public services, and some scholars explain public services from the perspective of public service values. It is believed that the concepts of "public goods" and "public services" are interchangeable or at least blurred. Public services are activities that provide a variety of tangible or intangible objects with the goal of maximizing public interest. Some scholars distinguish between public goods and public services, and believe that public services are a form of existence of public goods. Public goods generally refer to physical and result products, while public services refer to non-physical and process products. Some scholars explain public services from the perspective of government functions, arguing that public services are government-driven and provide public services to all citizens. Some scholars define public services from the perspective of public service needs and believe that the provision of public services is to meet the publ ic needs of society. In short, no matter from what angle the public service is defined, public service is always connected with the government to meet public needs and achieve the maximization of public interest as the goal. It is both a special product and an activity.

\subsection{Economic Basis of Government's Provision of Public Services}

Public goods are products with non-exclusive and noncompetitive characteristics. Public services, like public goods, are also non-exclusive and non-competitive. Nonexclusiveness refers to the characteristics of being unable to exclude unpaid people from enjoying such services because it is technically impossible or too costly. Non-competitiveness means that adding one person to the service will not affect others' enjoyment of the service. service. Under such circumstances, consumers lack the incentive to pay for public services, resulting in "free-rider" behavior. Therefore, no market entity is willing to provide public services. This has become the basis for the legitimacy of the government in providing public services.

\subsection{Before the 20th century: limited government role}

Prior to the 20th century, the governments of major industrial countries did not play the role of collecting high taxes and 
using them for public programs such as medical care, pensions, education, and social assistance. From the 16th to the 19th century, as the major Western countries were in the period of primitive capital accumulation, mercantilist doctrines and policy systems dominated. This theory holds that wealth is equivalent to gold and silver currencies. In order to achieve wealth accumulation, the government should protect industry and commerce through legislative and administrative means and try to make money flow into the country. Government intervention during this period was mainly limited to the field of circulation. Since the 19th century, liberalism has become the dominant theory of government intervention in economic limits. Adam Smith absorbed the views of the peasant school to criticize mercantilism. In The Wealth of Nations, he assumed that the market is efficient and self-regulating, and government intervention will undermine the market's self-regulating function. This led to his definition of government functions: (1) protecting national security from external invasion; (2) protecting personal security in society from being invaded and oppressed by others; (3) building and maintaining certain Public facilities and utilities that the private are unwilling to run. In addition to the above three functions, the market should play a role.

Under such circumstances, the government limited its actions to national defense, domestic security, administration, basic education, poverty reduction, and infrastructure construction. The social public voluntarily conducts assistance actions, and social organizations play an important role. The public can also join various private federations, such as fraternities, mutual aid societies, and credit unions. At that time, education and medical care were provided by private schools, private hospitals, etc., and the public could purchase the services needed from these private institutions.

\subsection{Early 20th Century to 1950s and 1960s: The government gradually expanded its functions to monopolize the provision of public services}

In theory, the 20th century British and American normative economics theory holds that market failures exist in the market economy, and that public goods, natural monopolies, externalities, and information asymmetries will cause the allocation of private market resources to reach Pareto optimality. Under this theory, public goods are non-exclusive and non-competitive, so the market cannot provide the public goods that society needs, and the government needs to provide them. In short, this theory holds that the government should and has the ability to correct market failures and calls on the government to intervene in the economy. Market failure has become a prerequisite for government intervention in the economy. After the Second World War, Keynesianism prevailed. Keynes believed that insufficient effective demand was the normal state in the economy, and the economic crisis resulted from it. The government's intervention was the only feasible way. The government was given a new function: stabilize the economy to achieve full employment.

With regard to socio-political events, the two World Wars expanded government functions. The war has increased government spending, partly for combat, and partly to comfort the wounded and wounded soldiers, their families, and rescue refugees. The Great Depression of the 1930s changed the public's understanding of government functions and believed that the government should assume the function of preventing risks.

This change is mainly reflected in Roosevelt's "New Deal" and the development of the welfare state. The Roosevelt's "New Deal" in the United States implements a social security system that covers the entire working class, invests a lot of financial expenditure in building public infrastructure, creates job opportunities, and regulates financial markets. In the 1940s and 1950s, many Nordic countries turned to a "mixed economy" and a "welfare state." The welfare state not only extends government functions to household cash benefits, allowances or public services provided directly by the government, price controls, housing policies, work environment regulations, work safety legislation and environmental protection policies, as Vito Tanz concluded: " The purpose of the new expenditure plan is no longer as previously announced - - to correct market failures or redistribution of income, but to reduce various risks. These risks may reduce the actual income of the public or hinder income growth include - Never received education, rarely received training, severe illness, old age, frailty, unemployment, support for large families, etc. Some countries have also taken into consideration gender and ethnic factors and formulated corresponding economic policies. "

\subsection{Since the 1980s: marketization of public services}

In the 1970s and 1980s, due to the fact that the omnipotent government was not established, the government monopolized public services caused various problems. First, due to the lack of an effective competition mechanism for the provision of products and services, the lifelong employment system of government officials and other reasons, the government's lack of motivation to provide public services to reduce costs has led to inefficiencies. Secondly, the government's monopoly of public services has continuously deteriorated the government's financial situation. From the second half of the 19th century to the beginning of the 20th century, government expenditures in developed countries accounted for about $10 \%$ to $13 \%$ of GDP on average, of which subsidies and transfer spending accounted for GDP is $1 \%$. In the 1990s, government spending in major developed countries rose to between $40 \%$ and $50 \%$ of GDP, and subsidy and transfer spending rose to $20 \%$ of GDP. This has overwhelmed the governments of some western countries, which is manifested by the high level of public debt. In some countries, the payments made to future beneficiaries in the pension and medical insurance systems can only be paid from the contributions of new members. European countries even have debt crises. Third, the provision of public services by the government has a crowding out effect on the private sector. Government expenditure funds come from high taxes 
collected from the public, which inhibits private sector investment and consumption, and also promotes the "freeriding" behavior of the public. It relies heavily on welfare programs provided by the government and inhibits individual labor. Will.

In terms of theory, public choice theory, polycentric governance theory, and new public management theory have promoted market-oriented reform of public services. In particular, James M. Buchanan, a representative of public choice theory, proposed that government officials also have the motivation to maximize their own interests, instead of pursuing the maximization of public interests as traditionally assumed. And he believes that "market defects are not a good reason to refer the problem to the government" Based on the above assumptions, the government's functions are restricted. The theory of polycentric governance and the theory of new public management advocate that the government should become a public service provider with individuals, enterprises, communities, and non-profit organizations.

In terms of practice, in the 1980s, countries such as Britain, the United States, France, and New Zealand set off a wave of marketization of public services. In particular, the reforms of the Thatcher government in the United Kingdom and the Reagan government in the United States are the representatives. Specific measures for public services include promoting the marketization and socialization of public services, making up for insufficient government financial and service capabilities, determining the quantity and quality of certain public services, inviting tenders from the private and non-profit sectors, and purchasing public services by governments. Production is given to the private sector; the private sector participates in the construction of infrastructure, and the private sector has the right to investment income and can charge consumers to recover costs.

\section{RESULTS AND DISCUSSION}

\subsection{There is no universal government, and the marketization of public services is an inevitable trend}

Market failure, economic fluctuations, and income distribution do not all provide rationality for government intervention in the economy. However, government intervention is not omnipotent. Government intervention in the economy can also cause "government failure". Sometimes government failure is more harmful to society than market failure. Bigger. The market is still the best means of resource allocation and should play its decisive role in resource allocation

This judgment is of significance to China's government economic function transformation. From a global perspective, the "slow growth of government finances and the rapid growth of people's demand for public services" are the common challenges faced by public services in countries around the world. Judging from the actual situation in China, on the one hand, China is currently in a period of gear shifting from high speed to medium and high speed growth. The slowdown of economic growth will inevitably slow down the growth of fiscal revenue. The structural reform of the supply side also puts forward the goal of "reducing costs", and "reducing taxes and fees" is an inevitable measure to reduce costs. On the other hand, since the "Twelfth Five-Year Plan", expenditures for people's livelihood projects such as medical care, education, and employment have continued to increase, and rigid expenditures are difficult to reduce. Economic development and changes in social concepts have prevented the government from returning to the pre-20th century StatusBasically, no public benefit plan is provided. The fiscal work conference at the end of 2017 also proposed to keep the active fiscal policy orientation unchanged. Reduced fiscal revenue and rigid fiscal expenditures have put greater pressure on China's finances. The market-oriented reform of public services and the role of private, corporate, and non-profit organizations have both historical and theoretical basis, and are also a necessity of reality.

\subsection{The government should play the necessary regulatory functions}

Although the western governments before the 20th century only assumed very few public service supply functions, the society still operated well with the efforts of various social organizations. However, the government monopolized public service provision period brought about credit crises and financial crises to the government, which also caused the public to have a free-rider idea, which harmed fairness. Therefore, the government should grasp the boundary with the market and seek a balance between the government and the market.

In theory, the market is the best means of resource allocation, but it does not mean that the market economy is perfect. Due to externalities, monopoly issues, and asymmetry in public goods and information, market allocation of resources cannot reach Pareto optimality. With the development and complication of the market, it has been discovered that laissez-faire market competition will also bring problems such as unequal income distribution and economic fluctuations. Because both the government and the market have certain defects, the two are not a substitute relationship, but should complement each other and be organically combined.

The marketization of public services includes returning some public service provision functions to the market. Under such circumstances, some citizens may not be able to purchase public services that were free of charge by themselves, and some citizens may pay higher prices. It is unrealistic for the government to sit idly by in this situation. It must assume more supervision responsibilities and use economic policy tools instead of administrative tools for supervision. Vito Tanz advocated that the government play a "free paternalistic" role. On the one hand, assume more responsibilities in improving market efficiency and increasing transparency. On the other hand, guide citizens. For example, individuals are required to purchase auto insurance, send their 
children to school, and individuals are required to purchase basic medical insurance. These "parental" practices replace the services that previously involved public expenditure.

\subsection{Strengthen the cultivation of social organizations and strengthen the capacity of social organizations}

Looking at the evolution of the functions of Western governments in the provision of public services, we can conclude that with the development of society, the evolution of theory, changes in public understanding, and the occurrence of specific historical events. The scope and responsibilities of the public service provided by the government are generally expanding: from the defense duties of Adam Smith's gradual expansion to the prevention of risks for each social public. But the main body of supply has developed from the supply of social organizations to the government monopoly supply, and then to the joint supply of government and private organizations such as private enterprises and non-profit organizations.

Therefore, in the process of China's public service marketization reform, the government should pay attention to the development of social organizations. Specific measures include the appropriate withdrawal of the government in the field of social management, the provision of certain policies and financial support in the early stages of the establishment of social organizations, and the establishment of a good institutional environment for the development of social organizations.

\subsection{Rethinking the boundaries of government functions and adapting to the wave of globalization}

With the further development of globalization, we need to think about the boundaries of government services. Globalization has brought about increased externalities and relationships between countries. The environment, financial markets, global terrorism, transnational crime, climate change and global warming, and global infectious diseases cannot be tackled by a single government alone, and there are The problem governs the phenomenon of free-riding, so the urgency of governments to jointly deal with public goods and provide public services is increasing. The new crown pneumonia epidemic reminds countries to establish an effective and long-term mechanism in the provision of global public services to better cope with the globalization wave.

\section{CONCLUSION}

Restricted by factors such as system and finance, China still has a shortcoming in the provision of public services. Recalling the changes in the public service provision functions of Western governments, the Chinese government should insist on the orientation of marketization of public services; effectively play the role of government supervision, while maintaining a more transparent market environment and guiding citizens on the one hand; attaching importance to fostering social organization capabilities ; actively carry out international cooperation, so that we can realize the historic leap of building a well-off society in an all-round way.

\section{REFERENCES}

[1]Editwell, John et al. New Palgrave Economics Dictionary [M]. Economic Science Press, 2016. Volume VIII. P653.

[2]Buchanan: Free Markets and Countries, Beijing University of Economics Press, 1988, "Translator's Foreword", p3

[3] Vito Tanz. Government and Market [M]. Commercial Press, 2014.

[4] Wang Jing. Enlightenment of market reform of public service in western countries [J]. Economic Management, 2005 (19): 11-14.

[5] Sun Liang. Research on Fiscal Sustainability and Tax Reduction Policy Options [J]. China Price, 2018 (2).

[6] Lu Hongmei. The Evolution of Economic Functions of Western Governments and Their 